\title{
Nias Warrior's Armor and its Fundamental Values
}

\author{
Kezia Clarissa Langi ${ }^{1}$, Setiawan Sabana ${ }^{2}$ and Hafiz Aziz Ahmad ${ }^{3}$ \\ ${ }^{1}$ Faculty of Art and Design, Institut Teknologi Bandung, Indonesia \\ ${ }^{2}$ Faculty of Art and Design, Institut Teknologi Bandung, Indonesia \\ ${ }^{3}$ Faculty of Art and Design, Institut Teknologi Bandung, Indonesia \\ 1 kezialangi91@students.itb.ac.id, ${ }^{2}$ setiawansabana@yahoo.com, \\ ${ }^{3}$ hafizsan@yahoo.com
}

\begin{abstract}
Nias headhunter (human head collectors) was once a feared and victorious warrior. The society is famous of its complex social structures, anti-earthquake architecture, detailed wooden and stone statuary, along with its vicious warriors. Since the independence of Indonesia, war costume production stopped. Moreover, the need to pay taxes and daily necessities causes the once great warriors into abandoning his identity completely. For tourism purposes, war costume is produced with cheap materials and less details, resulting in losing its fundamental meanings. This paper aims to analyze Nias unique war costume, specifically the armor and its fundamental values based on the armor's structural design and materials. The data were obtained by ethnographic research in Nias Heritage Museum and the village of Bawomataluo. Literature research were done by collecting cultural and historical books, historical images, previous research article and journals related to Nias custom, history, and war issues. The data were then analyzed using the psychology of dress theory by creating a dialogue between the Nias armor and the self. The result shows that based on its structure, the armor shows 'magnificence' and according to its material, the armor signifies 'power'. By identifying the fundamental meaning of Nias war costume's fundamental values, the identity of the warriors can be an important heritage to Nias descendants and Indonesia society as a whole.
\end{abstract}

Keywords: armor, fundamental meaning, heritage, identity, Nias, psychology of dress

\section{INTRODUCTION}

Indonesian traditional clothing consists of both protective and aesthetic values, it shows the wearer's social status and contains fundamental values that derived from the local wisdom. Local wisdom is a special view of life that became unique, contains personality and identity of a community. It carries life strategies that manifest the activities of a community [1]. Fundamental values are seen through the decorative design and structural design of a clothing. Research shows that Indonesia is most famous of its traditional textile such as Batik and Tenun, due to years of a spiritual medium that provide values to the wearer [2]. However, as a structural design, a clothing offers more personal worth, considering a clothing is made mostly by measure and can be decorated based on the owner's liking. Indonesian clothing is categorized by daily 
wear, customary wear, wedding attire and uniform. Each of the categorized clothing is well developed by design, materials, pattern, and colors. The developments of each category can be seen through the amount of Indonesia's traditional clothing designers and the modern traditional clothing seen in Indonesia's academic graduation, weddings, and formal events. The only category that has not yet to be clarified after the independence of Indonesia is the war costume.

Around the world, the production of traditional armor stopped and its fundamental values needed to be analyzed. Ryan and Barnes' work regarding the armor in Japan and Korea stated the material per period and its development [3]. The research is important to acknowledge the journey of material from Europe to East Asia and possibly to Nias. However, the analysis of structure and fundamental values of the armor are not mentioned and needed to be address. In this paper, we report the investigation of fundamental values through the armor's structure and material. The armor has a unique structure and the development of materials shows how technology and values in Nias culture happened and developed. Although war costumes are not produced and used as its original purpose, it is important that Nias descendants recognize and appreciate their local values the same as their ancestors did. These values are an important heritage and can be used in their daily life as their identity, lifestyle or clothing.

\section{METHOD}

This research uses qualitative research with historical approach to discover the pattern of rituals, social behavior, or custom in Nias regarding the warlike society and war costume [4]. The psychology of dress theory analyzes the relationship between the armor and the wearer. It aims to unfold the fundamental values of Nias headhunter's armor [5]. Source of data by field research in Nias island were done from $22^{\text {nd }}$ until $24^{\text {th }}$ of August 2019. Source of data were 1) informants, including the Nias Museum of Heritage founder and the museum director, as well as the descendant of Bawomataluo Village's warlord, 2) documents, obtained from articles, journals, and books related to Nias, headhunters, history, and 3) historical images collected at the online collection of Nias Museum of Heritage, Troppen Museum and Quai Branly - Jacques Chirac Museum. Data were collected through in-depth interview, field observation, and literature study.

\section{RESULT AND DISCUSSION}

The war philosophy, warlike society, and war costume are three unbreakable links. To understand the war costume, it is important to have knowledge about the war philosophy and warlike society of Nias. The traditions, symbols, and meanings a costume has are taken from the philosophy and the society's common belief.

The consciousness of the art of dressing leads to personal vanity. In the psychology of dress, the outcome of dressing on creating impression, attributions, and social perception or behaviors. Dressing is perceived as well as the characteristics of perceivers of clothed individuals has a profound effect on what is perceived about others [6] A clothing protects an individual from fear. The fear is not only about physical aspects, but also psychological aspects, to be respected or to be liked. To understand the study, research of the Nias armor should be associated with its cultural meaning, the relationship between the armor and the self, and how it is influencing the body image.

Nias war costume is created to psychologically terrorize its enemy [7]. Every inch of the clothing item shows intimidation to everyone who sees it. The protective gears are made with oversize silhouette, pointy edges, and decorated with animal parts. The attacking devices are 
impressive and are well decorated with wood carving, animal claws, fossils, and powerful amulet. This paper will discuss the Nias armor structure, its meaning to the wearer, meaning of the perceivers, and its fundamental values.

\subsection{Nias War Philosophy}

The myth of Nias origin has various version but the same storyline, they were the descent of Lowalangi that divided into two, the North and the South [8]. The folklore continues to develop in many forms but in one essence: both started with a misty void; meaning death brings life. Nias with its warlike society contains a philosophy to dominate another, separates unsuitable conditions, and to believe that to kill is to give life [9]. Their belief is unconsciously consistent to their myth of origin. There are three reasons a village declare war: power, wealth, and pride. Nias society emphasis the 'pride' of a village into their life. The pride of dominance is seen among the constant rivalry with other village, and conflict of food. Nias society accentuate the production of war weaponry than agricultural equipment, therefor in the society, death by the cause of war is highly valued that the death of hunger [10] [11].

Nias is known for its headhunters and their stone jumping (fahombo batu) tradition. During the colonialization of the Dutch, the warriors were feared, in result, people are advised not to visit Nias outside Gunungsitoli area [5]. The tradition of head hunting and war were embedded in Nias through its warlike society. Production of manufacturing war items are highly more important than agricultural and farm tools [10]. The young boys of Nias, are trained to watch the older boys practice jumping a two-meter stone in order to do it themselves when they are older. This process is done to decide if they are worthy to protect their village as a warrior; either to attack their enemy or as the village guard [11]. Not every male can jump the two-meter stone as it is believed besides active training, they should be guided by an ancestor spirit. A man is worthy of this responsibility if he jumped the stone three times in a row, local belief said that the skill to jump the stone is hereditary [12]. This practice is risky considering the height of the stone, sharp objects put on the stone [13], protection gear on the leg area and elbow, and the landing zone are formed by a small space of sand. Unfortunate trainers can hurt themselves; the worst scenario is if they die during this practice. Therefore, being a warrior is considered a noble status and protected by the ancestor.

War, victory, and lost in Nias battle is influenced by a local priest (ere), it's helper in a shape of a wooden statue (adu), and the evil spirit (bekhu). Battles between villages often occur to defend the honor of the village. This action is called ëfabanuasa ndöra ba banuasa, kiki-kiri mbambatö i.e. a patriotic sense for the village is more important than kinship. To become a soldier, a long sequence of ritual is needed, however if someone manages to avenge a village, when he returns, he will be welcomed and appointed as a respected soldier [11].

\subsection{Armor Structure and its Fundamental Values}

As a warrior, a man is dressed according to the basic uniform that consist of protective gear and attacking device. A warrior can decorate such as adding personal touches or items that possessed spiritual strength [14]. To distinguish a friend or foe during war time, these personal touches are crucial to differentiate another warrior. The basic uniform of protective gear consists of helmet (takula tafalo), armor (oröba, name may differ due to its material), loincloth (saombö), necklace (kalabubu) and shield (baluse). The basic uniform of attacking device includes ceremonial knife (tolögu) and spear (toho) [15]. In conclusion, Nias war costume are 
fused with the wearer's characteristic. The decorative costume is made to scare the enemy, even though the enemy might be more powerful [7].

Nias armor's basic structure is formed by a vest shape, front opening, A-line silhouette and a straight bold shoulder, with a circular decoration on the neck [Fig 1]. This basic structure can be seen through the early $19^{\text {th }}$ century from the usage of animal skin and natural fiber, until early $20^{\text {th }}$ century armors created by metal, and later, combining different materials to achieve more personalization [Fig 2]. After the independence of Indonesia, the armor is more common to be produced by cotton. The body structure of Nias people are petite, therefore it is understandable if they created a 'power suit' with bold shoulder and an A-line silhouette. The silhouette manipulates the body shape into a massive upper body by creating a longer and broad shoulder and torso. The circular decoration has a function to protect the neck. Psychologically, people with broad shoulder are associated with masculinity and power. The same emotion is portrayed when a warrior wears the armor.

Before having access to other materials, Nias armor was made from natural fibers. For the armor, it is woven by a bast fiber called isitö. Traditionally, it was believed that isitö fibers gave power to its wearer. Later, there is evidence of Nias armor created from tiger skin. Nias does not have tiger living in its territory, however there is a traditional ceremony of 'Famatö Harimao,' which is a ceremony of remission of sins, as a tiger statue being carried around the village, then broken into pieces and thrown in a river [15]. Nias believe that a tiger possesses a power to attack, therefore decoration of the ceremonial knife is constructed of tiger claws. A tiger in Nias symbolize strength and cleverness. Nias is known for its wood and stone carvings. In Nias megalithic stone carvings, an alligator signifies wisdom [16]. Alligator lives in Nias and there are traces of the armor made by alligator skin, the texture and detail of the armor shows a deadly elegance of a calm and vicious alligator [17]. An alligator in Nias tradition represent the underworld and conveys the punishment of the ancestors. [18]. Moving on the metal or tin material, once again the alligator skin is present. The metal material is cut and weld to mimic the alligator's tail, shaped at the back of armor. Because metal can be weld, the A-line structure can be clearly achieved by pattern drafting a circular shape.

Although Nias armor has a basic structure, each armor is owned personally by a warrior. Each warrior can personalize his armor by decorating it with natural objects, palm fibers, spikes, painting, or embroidery. As the advance technology of decorating was increasingly introduced by the influence of the overseas merchants and researcher by time, the Nias armor was impacted by the advance decoration [Fig 3]. The more decorated, the more pride a warrior has. It took time to slowly decorate the armor, sometimes the material is obtained by trading, stealing, and hunting. This characteristic shows the warrior's creativity and wearing an armor shows a 'magnificence' value for the wearer, as for the material, it shows 'power'.

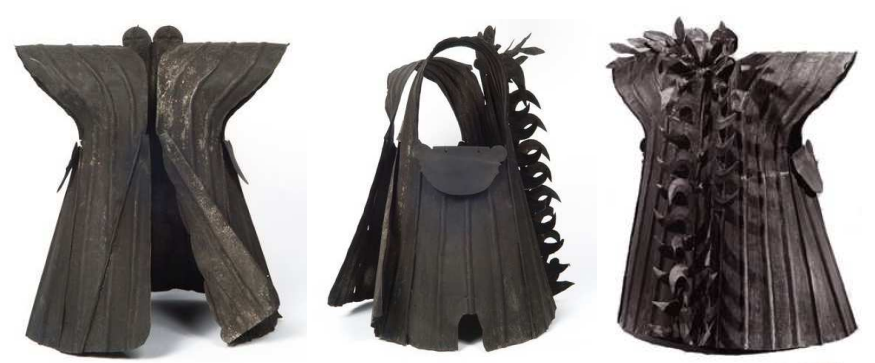

Fig 1. Front, side, and back view of Nias armor's basic structure Source: quaibranly, n.d 

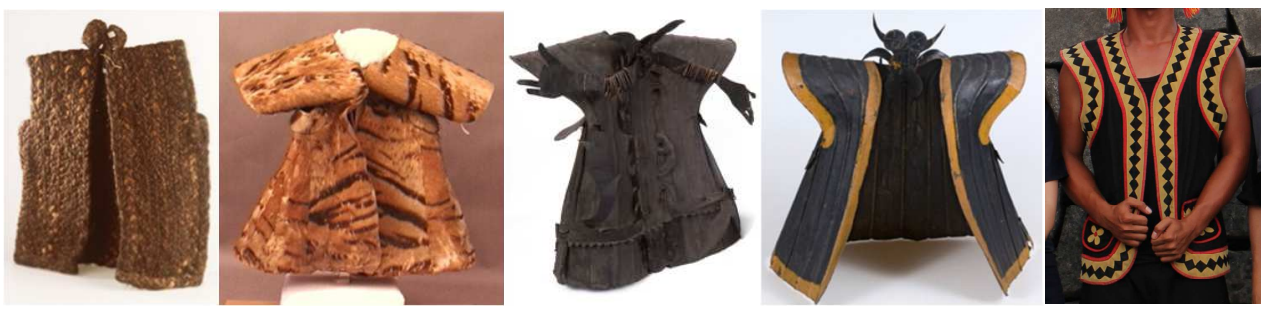

Fig 2. Nias armor created by different material yet the same basic structure (a) Baru lema'a made from braided natural fiber, (b) Oröba oeli harimao made from tiger skin, (c) Baru oröba, made from iron and rattan, (d) Baru oröba, made from mixed media of tin, carcass leather, crocodile or anteater skin and rope as well as a painting decoration., (d) Baru Nukha, sewn from a piece of cloth, usually decorated with embroidery or printed pattern.

Source: wereldculturen, n.d, wereldculturen, n.d, quaibranly, n.d, wereldculturen, n.d, Langi, 2019

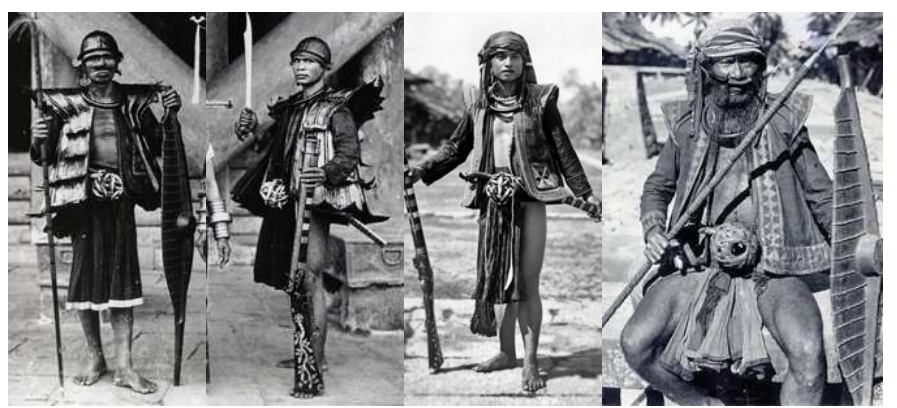

Fig 3. Personalization of Nias armor created by the warriors themselves, with the same basic structure Source: museum-nias, n.d

\subsection{Other Armor and its Characteristics: Japanese Samurai}

The Japanese armors was displayed at the Metropolitan Museum of Art and the characteristic has been investigated [19]. The armor worn by the samurai are seen as "a creation of art". The process was made through a strict code of honor around loyalty, self-discipline, obligation, and the shame of failure. A samurai values his sword and armor, both would be handed down hereditary. An Armor's ensembles qualify as multimedia art as they embody the spirit of several Japanese art forms. The jutting planes of tiles are architecture in miniature; the curled flaps of certain helmets introduce pagodalike curves; the grimacing masks portrays kabuki; The scales' lacing provides color, texture, pattern and flexibility.

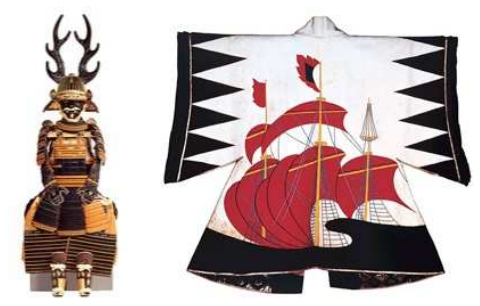

Fig 3. Japanese samurai armor Source: nytimes, 2009 


\section{CONCLUSION}

There are several local wisdoms that Nias is well known of, the jumping stone (was featured on Indonesian currency) and the war dance. Both are associated with Nias warrior. The island was mentioned in several historical writing as an island of headhunters and slave traders. The society was portrayed as an eerie tribe. However, Nias tribe can be considered a creative craftsman, they sculpt stones, carve woods, weld metals, weaving fabrics, and embroidering textiles. As a former animistic, each craft contains a special symbol and meanings. This also applies to the Nias armor. An armor is personally decorated and contain personal meanings, as a whole an armor shows 'magnificence' of the wearer. Today, Nias is slowly being recognized as one of Indonesia's tourist site. The once feared island are regaining popularity for its nature, architecture, and local tradition. It is important for us to remind the younger generation about the 'magnificence' and 'power' as one of Nias fundamental values that was analyzed based on its armor and material. The pride and diligence that once was embedded in Nias tribe should be owned by the people of Nias today.

Future research regarding Nias war costume can be done by analyzing its fundamental values on other structure as one of Indonesia's heritage. New study can be developed with other expertise.

\section{REFERENCES}

[1] Y. Harefa, "NIAS LOCAL WISDOM: A CRUCIAL ASSET IN PROMOTING NIAS TOURISM (A View Point)," in Advances in Social Science, Education and Humanities Research (ASSEHR), 2018, pp. 246-249, doi: https://doi.org/10.2991/icoposdev-17.2018.51.

[2] K. C. Langi and P. Shinmi, "An Analysis on Characteristics of Ancient Indonesian Textiles (I)," J. Korean Soc. Costume, vol. 66, no. 6, pp. 67-78, 2016, doi: http://dx.doi.org/10.7233/jksc.2016.66.6.067.

[3] J. Ryan and G. Barnes, "Armor in Japan and Korea Joseph," Encycl. Hist. Sci. Technol. Med. Non-Western Cult., pp. 1-16, 2014, doi: DOI 10.1007/978-94-007-3934-5_10234-1.

[4] P. J. Buckley, "Historical Research Approaches to the Analysis of Internationalisation," Manag. Int. Rev., vol. 56, pp. 878-900, 2016, doi: DOI 10.1007/s11575-016-0300-0.

[5] V. Puccioni, Tanah Para Pendekar: Petualangan Elio Mondigliani di Nias Selatah Tahun 1886. Jakarta: PT Gramedia Pustaka Utama, 2016.

[6] K. Johnson, S. J. Lennon, and N. Rudd, "Dress, Body and Self: Research in the Social Psychology of Dress," Fash. Text., vol. 1, no. 20, pp. 1-24, 2014, doi: https://doi.org/10.1186/s40691-014-0020-7.

[7] K. C. Langi, Interview with Nata'aluhi Duha. 2019.

[8] J. M. Hämmerle, Asal Usul Masyarakat Nias: Nias: Yayasan Pusaka Nias, 2015.

[9] J. Sumarjo, Estetika Paradoks. Bandung: Kelir, 2014.

[10] M. A. Viaro, "Ceremonial Sabres of Nias Headhunters in Indonesia," Arts Cult., vol. 3, pp. $150-171,2001$.

[11] S. Hadiwinoto, R. Joedodibroto, K. Wiradnyana, E. Suhartono, and C. P. Kubontubuh, Nias, Dari Masa Lalu ke Masa Depan. Jakarta: Badan Pelestarian Budaya Indonesia (BPPI), 2008.

[12] W. G. Sasongko, "Dari Lompat Batu hingga Tari Perang," INDONESIA.GO.ID, 2019. [Online]. Available: https://indonesia.go.id/ragam/budaya/kebudayaan/dari-lompat-batu-hingga-tariperang. [Accessed: 31-Aug-2019].

[13] A. Z. Sirefar and Syamsudin, "Tradisi Hombo Batu di Pulau Nias: Satu Media Pendidikan Karakter Berbasis Kearifan Lokal."

[14] K. C. Langi, Interview with Johannes Maria Hämmerle. 2019.

[15] M. P. Nias, "Customs," Museum Pusaka Nias. [Online]. Available: https://museum- 
nias.org/en/nias-customs/. [Accessed: 31-Aug-2019].

[16] P. M. Taylor and L. V. Aragon, Beyond the Java Sea. Washington D. C: The National Museum of Natural History, 1991.

[17] M. B. A. Saleh, Seni Patung Batak dan Nias. Jakarta: Direktorat Jendral Kebudayaan Departemen Pendidikan dan Kebudayaan.

[18] J. M. Hämmerle, Pasukan Belanda di Kampung Para Penjagal: Perlawanan Warga Desa Rumpun Fau di Nias Delatan dan Kronologis Berbagai Peristiwa Sejarah di Nias Dalam Dokumentasi di Luar Negeri. Nias: Yayasan Pusaka Nias, 2013.

[19] R. Smith, "Wise Warriors, Artfully Attired," The New York Times, 2009. [Online]. Available: https://www.nytimes.com/2009/10/23/arts/design/23samurai.html. [Accessed: 02-Jan-2019]. 